\title{
PREPARATORY STAGES OF PHEOSIA PORTLANDIA Hy. Edw.
}

\author{
BY HARRISON G. DYAR, BOSTON, MASS.
}

\section{Pheosia portlandia Edwards.} 1886. - Hy. Edw., Ent. amer., ii, r68, Pheosia.

I891. - Smith, List lep., No. I287. descherei Neumoegen.

I892. - Neum., Can. ent., xxiv, 227, Notodonta.

Egg. - Hemispherical, the base flat; not shining, whitish green; diameter $1.2 \mathrm{~mm}$. Under the microscope it appears densely covered with minute white granulations, except at the micropyle, where is a single larger granulation, surrounded by a pale green ring, from which the granulations are absent. The granulations are larger in the area immediately around the micropyle, and diminish in size towards the base of the egg, becoming very minute and almost lost on the under side. The larva hatches by eating a semicircular hole in the side of the egg, leaving the rest of the shell. Eggs laid singly on the leaves.

First stage. - Head slightly bilobed, black and shining; labrum paler, slightly whitish; a few pale hairs; width $0.65 \mathrm{~mm}$. Joint I2 is hardly perceptibly enlarged dorsally; body cylindrical, diminishing a little in size posteriorly; no traces of a caudal horn; feet normal, the anal pair used in walking. Color pale white, cervical shield and thoracic feet black, abdominal feet, except the last pair, blackish outwardly; setiferous dots concolorous, the setae pale, short. As the stage advances the anal plate, all the abdominal feet outwardly and the piliferous dots become black. The dots are large and distinct, row I on joints $5^{-1} 2$ almost in line with row 2 except that on joint $\mathbf{I} 2$ there is a single large dorsal dot instead of row $I$ but it bears two setae; row 3 lateral; rows 4 and 5 subventral, smaller. Joint 12 becomes more enlarged, but there is still no horn, till just at the end of the stage a purplish shade appears about the dorsal dot. A row of subventral purplish spots appears and the body becomes greenish.

Second stage. - Head hardly bilobed, rounded, narrowing a little to vertex; smooth shining pale brownish, vertices of lobes nearly black, labrum whitish, jaws and ocelli black; width $1.0 \mathrm{~mm}$. Body slender, cylindrical, with a short, rounded, conical process on joint 12 dorsally, bearing the two setae of row I almost at its vertex; other setae fine, blackish, situated as before, their bases very slightly elevated but not discolored. Body pale whitish green, thoracic feet blackish with a dark red subventral line along their bases, represented by small spots above the abdominal feet. Process on joint 12 faintly purplish. Cervical shield and anal plate not distinguishable. Later a yellowish shade appears substigmatally, the subventral band below it is purplish, broken, occurring on the bases of the legs. Abdominal feet green, tinged with purplish on the outside.

Third stage. - Head rounded, and narrowing a little above, very slightly bilobed, flattened in front so that the lateral outline is nearly triangular; straw yellow, not shining, ocelli and jaws inwardly brown, labrum whitish; width $1.6 \mathrm{~mm}$. Body cylindrical, joint $\mathrm{i} 2$ enlarged and bearing a fleshy process in the shape of a horn, $0.4 \mathrm{~mm}$. long and directed straight upward. Setae short, pale, row $I$ on joint 12 diverging from the horn before its tip, their concolorous bases slightly elevated and, under a lens, with a minute black dot. Color uniform pale green, yellowish at the sides with an interrupted purplish red band along the bases of the legs, most well developed on the thoracic segments. Spiracles black, narrowly paler 
centrally. Feet pale, purplish tinged outwardly; horn reddish. Later the spiracles are surrounded by whitish, outside which is a faint purplish space, which on joint 3 extends over the dorsum. Horn $0.8 \mathrm{~mm}$. long. At the end of the stage, the purplish shading overspreads the whole lateral region, but is sharply defined above subdorsally, leaving the dorsum broadly green. Joint 2 is all green, as is the venter between the legs. A faint line reaches straight up from the spiracle on joint 12 to the horn.

Fourth stage. - Head shaped as before, yellowish green, slightly mottled with brown on the sides of the front; ocelli brown, jaws brownish, antennae reddish, labrum whitish; width $2.4 \mathrm{~mm}$. Body slender, joint $\mathrm{I} 2 \mathrm{en-}$ larged, with a thick, conical, fleshy horn from a very large base, rounded at the tip, pointing straight up and bearing two minute divergent setae; length about $\mathrm{I} \mathrm{mm}$. The setae on the body arise from small, concolorous, rounded, shining warts, row 3 rather conspicuous, the rest minute. Dorsum broadly bright green, except on joints 2 and 3 , where it is shaded with purplish brown in a dorsal line extending over joint 3 laterally. Lateral region, subdorsal to substigmatal. shaded with purplish, bordered below by a heavier shade and emphasized on the bases of all the feet, except the anal, by a nearly black shade. Feet purplish; venter green; horn purplish brown with a line running down to the spiracle. Spiracles black, white centrally and surrounded by a broad white ring, except the one on joint 2. Anal plate large, green, but quite smooth and inconspicuous. Later, a livid purplish tint spreads slightly over the body, and there is less contrast between the dorsal and lateral regions. The horn is $2 \mathrm{~mm}$. long, and is colored livid purplish with a dark purple brown stripe down the side, running behind the spiracle.

Fifth stage. - Head shaped as before; green, but covered with a brown shade except over the clypeus and a space immedi- ately around it, densely mottled with green spots; jaws brownish, ocelli minute, black, labrum pale; width $3.9 \mathrm{~mm}$. Body smooth, setae very minute, joint 12 much enlarged, the horn very well developed, becoming 3 $\mathrm{mm}$. long and thick at base; anal plate large, nearly circular, excavated anteriorly, coarsely granular with a knob-like prominence in the center. Body at first nearly green, but overspread with a livid purplish shade, a band over joint 3 , lines on the feet on joints 7-10 and a stripe from vertex of horn to subventral region purplish black. Bases of horn before and behind the black stripe, pinkish. Anal plate green with reddish border. Thoracic feet reddish. Spiracles white in a narrow black border, surrounded by white and outside this by a purplish black ring. Abdominal feet red each side of the black line. As the stage advances, the head and body become shining, light, livid, greenish purple, marked as before; venter centrally green; anal plate entirely reddish, deep red on the circumference. The black stripes become paler, the spiracles entirely black inside of their white border. Still later a diffuse, but evident, ocher yellow substigmatal line appears, ending abruptly on the lower side in a greenish shade, reaching up above half-way on the spiracles. The purple color of the body is very pale and becomes more and more livid and greenish. Length of larva $50 \mathrm{~mm}$.

Cocoon. - The larva went just beneath the surface of the ground and formed a cell lined with silk.

Pupa.-Cylindrical, rounded at both ends, thickest through the $4^{\text {th }}$ abdominal segment. Cases comparatively small, wrinkled; cremaster, two short thick spines, some distance apart which point outwardly at an angle from the body. Color very dark brown, black on the cases and the back. Length $2 \mathrm{I}$ min.; width $7 \mathrm{~mm}$.

Food plant. - Willow (Salix).

Larvae from Portland, Oregon.

The moths differ from Pheosia dimidiata 
H.-S. in that the fore wings are much darker. The male has no white markings except the apical streak, and the transverse lines, usual in the Notodontidae, can be seen faintly crossing the wing, while in $P$. dimidiata they are quite obsolete except at the internal margin. T. a. line very faint, defined by the inner edge of the black cellular patch, obso- lete below median vein, but below submedian fold very distinct, white, sharply produced inward and bordering the fawn colored patch. T. p. line from costa along discal cross vein, either straight or sharply dentate on the veins, lost between veins 2 and 3 , but distinct on internal margin in a short white dash, reaching internal vein.

\title{
OVIPOSITION OF A HOMOPTEROUS INSECT IN YUCCA.
}

\author{
BY C. H. TYLER TOWNSEND, LAS CRUCES, N. MEX.
}

On May 15, I89r, a grayish homopterous insect, one of the Fulgoridae, or lantern-flies, was found very numerous on leaves of rucca angustifolia. It was also found on $r$. macrocarpa (?)*. Specimens are determined by Dr. Uhler as Oecleus decens Stål.

At the same daze on which the insects were found, it was noticed that the leaves of $r$. angustifolia were largely covered with very small patches of a pure white, woolly or cottony, fluffy material, arranged in more or less irregular rows. They were found to be punctures consisting of slightly raised swellings of the surface of the leaf, each swelling being marked by this cottony covering. They exhibited much the general appearance, at first sight, of colonies of a small white cottony scale. These are the egg-punctures. They are always placed on the upper side of the leaf, and usually, if not always, near the tip or point. Superficial examination shows only this woolly, snow-white, fluffy substance, apparently containing nothing, but covering the slightly raised puncture in the leaf. The above fulgorid was found wherever this woolly material occurred, usually on and about it, and consequently raised the question in my mind of some connection between the two.

On May 2I, the punctures were carefully examined and found to contain eggs. The

* This species may be $Y$. baccata. egg measures $\frac{4}{5} \mathrm{~mm}$. in length, by $1 \mathrm{~mm}$. in width. Examination on May ${ }_{5}$ had disclosed no eggs whatever, and I imagine that they were not yet all deposited at that date. The presence of the insects would perhaps indicate that they were in the act of ovipositing and preparing the leaves for the reception of the eggs. The leaves of $r$. macrocarpa (?) contained, at that date, no punctures. Though I have not at any time observed the insects making these punctures, I still feel confident that the latter belong to this fulgorid, since there is no other insect frequenting the Yuccas that could make them. I may add that $I$ have found the abdominal saws or pincers of a female specimen with some of the same white fluffy substance still adhering to them.

On May 3I, plants of rucca augustifolia were found to be thickly oviposited in. Some plants had the tips of nearly every leaf covered with the white fluffy material. Numbers of this insect were present, many of them on the punctured portions.

On June 2, similar egg punctures were found on the leaves of rucca macrocarpa (?) marked by the same woolly material. Three specimens of an Oecleus, which Dr. Uhler says is the same as $O$. decens, were found clustered on the woolly punctures. They were, however, decidedly smaller than those previously found, and which had occurred only on $r$. angustifolia. I was inclined to 

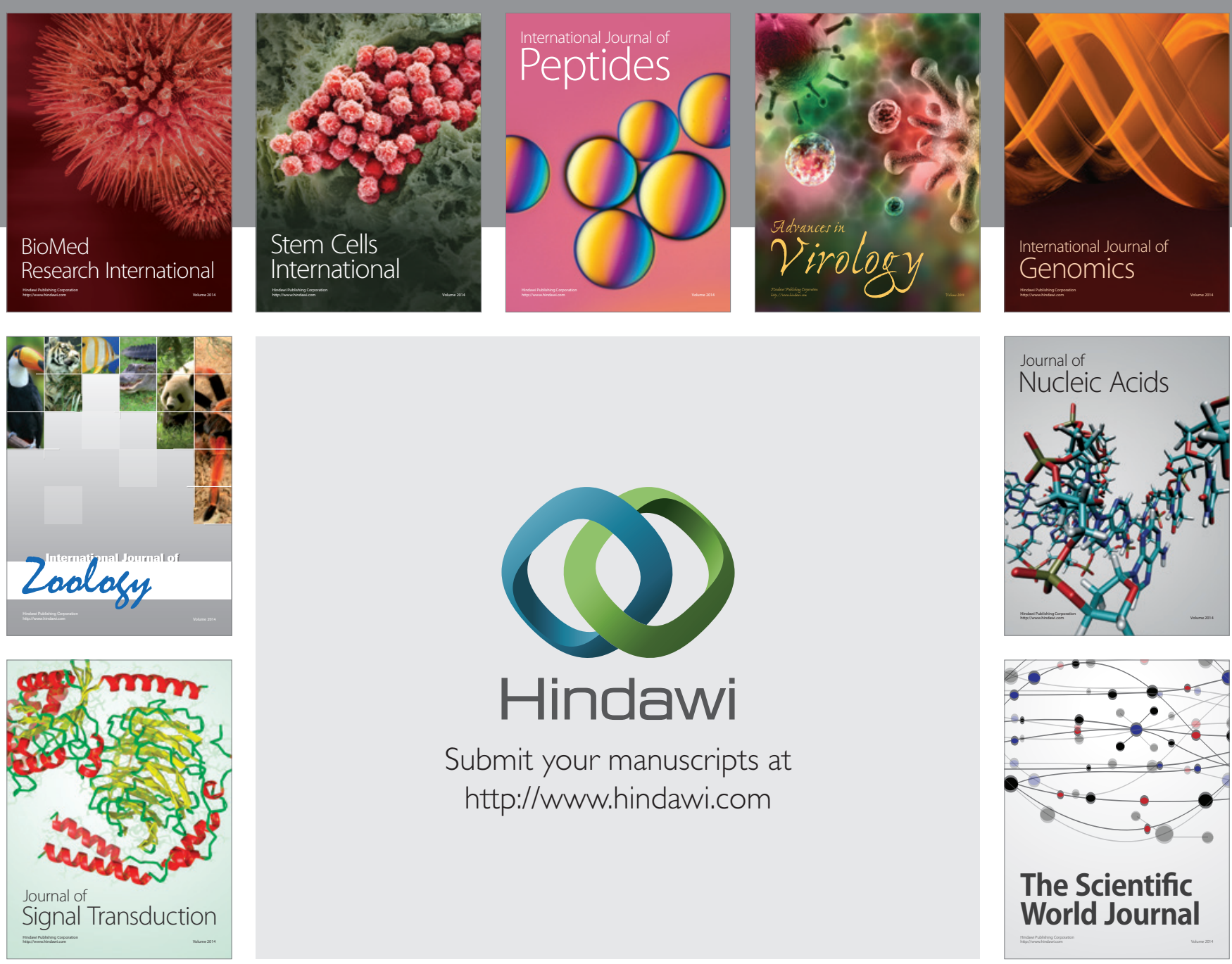

Submit your manuscripts at

http://www.hindawi.com
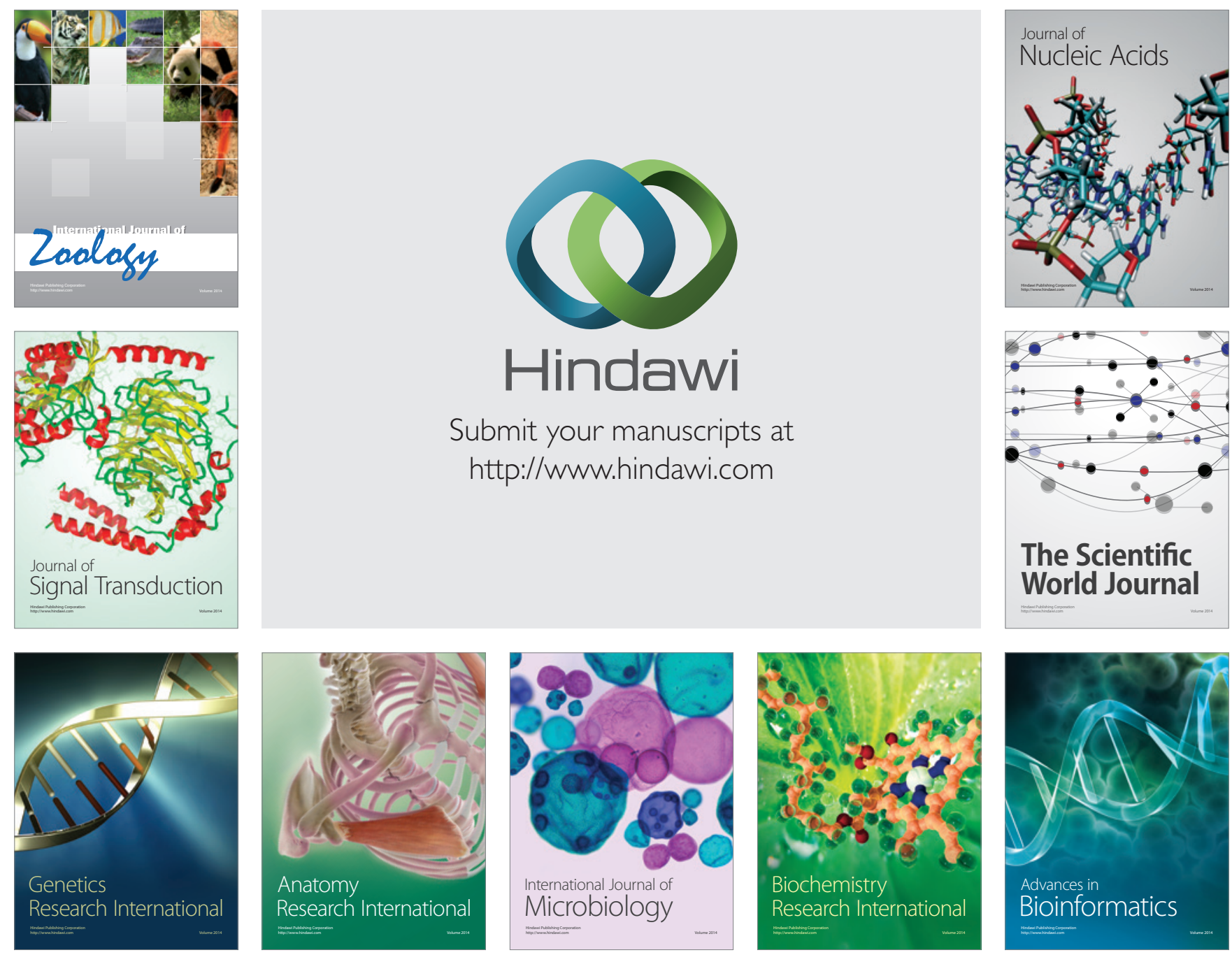

The Scientific World Journal
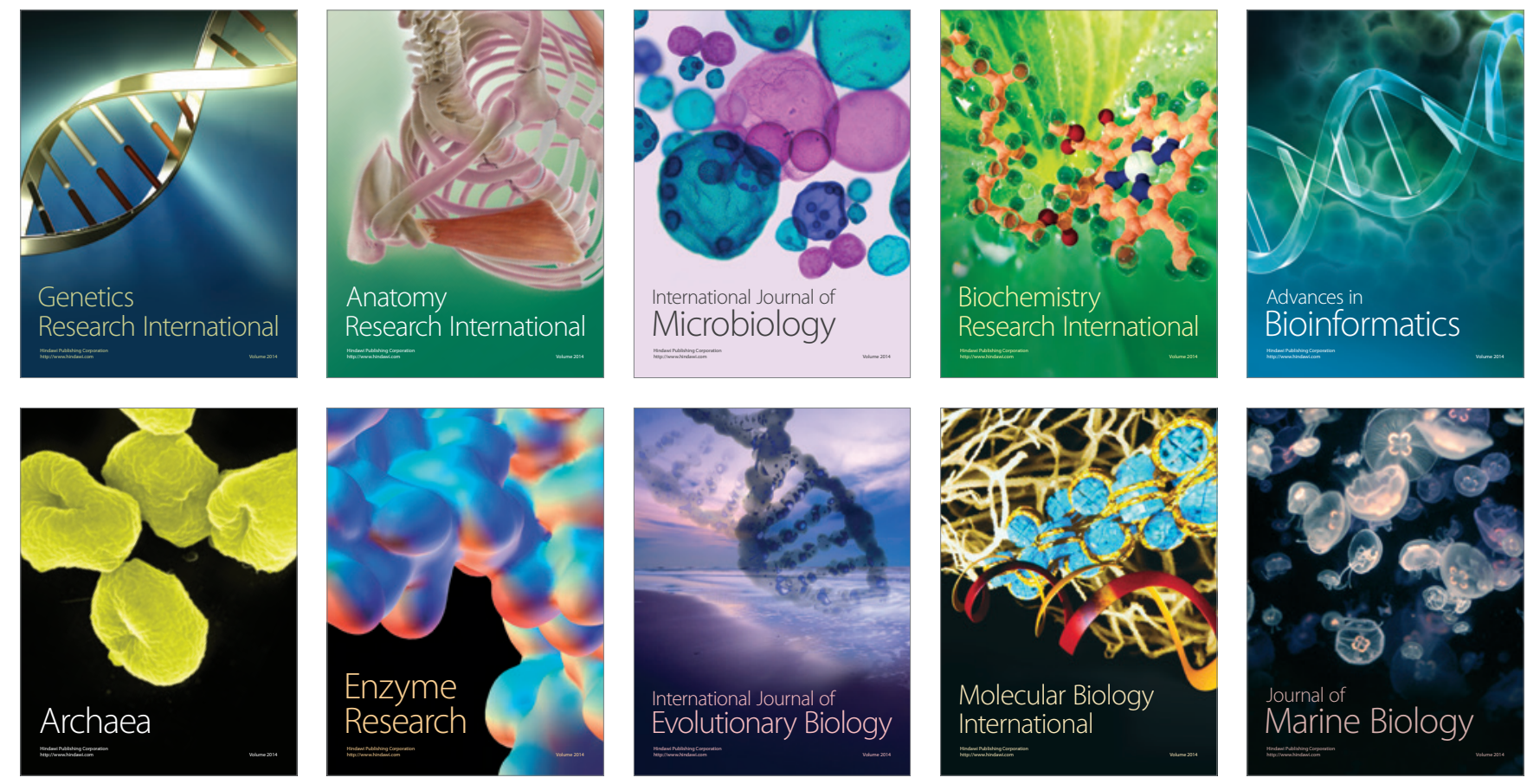